\begin{tabular}{|c|c|}
\hline Description: & $\begin{array}{l}\text { Levelized Cost of Heat }\left(\mathrm{LCoH}_{\text {sol,fin }}\right) \text { for solar thermal systems with overheating } \\
\text { prevention, in particular by using heat pipe collectors }\end{array}$ \\
\hline Date: & October 2018 \\
\hline Authors: & $\begin{array}{l}\text { Bert Schiebler (ISFH Hameln), Federico Giovannetti (ISFH Hameln), Stephan } \\
\text { Fischer (IGTE Stuttgart) }\end{array}$ \\
\hline Download possible at: & http://task54.iea-shc.org/ \\
\hline
\end{tabular}

\title{
Introduction
}

Solar thermal systems are state-of-the-art devices to cover part of the heat demand for the domestic hot water supply and space heating of buildings. Depending on the system design and the heat demand more or less intensive stagnation periods can occur. Usually high stagnation loads require a complex hydraulic system design, affect the operational safety and lead to high maintenance efforts, which impair the costefficiency and the general attractiveness of solar thermal installations. To prevent overheating in solar circuits, different approaches are usually pursued. Most of them are based on cooling systems or collector draining strategies (drainback), which require additional components and control technology respectively. Other approaches avoid overheating directly in the collector, e.g. by using heat pipes [1] [2], thermochromic absorber coatings [3], thermal actuated valves [4] or other technologies, which increase the thermal losses of the collector at high temperatures. In the case of stagnation the maximum temperature in solar circuits using such collectors can be limited (see Figure 1) and vapour formation can be reduced or even completely avoided. Thus, the thermomechanical stress of several components is significantly lower compared to systems with common collectors. Within the scope of this report we evaluate the economic benefits of solar thermal systems with overheating prevention by considering maximum temperatures between 100 and $125^{\circ} \mathrm{C}$ in the solar circuit.

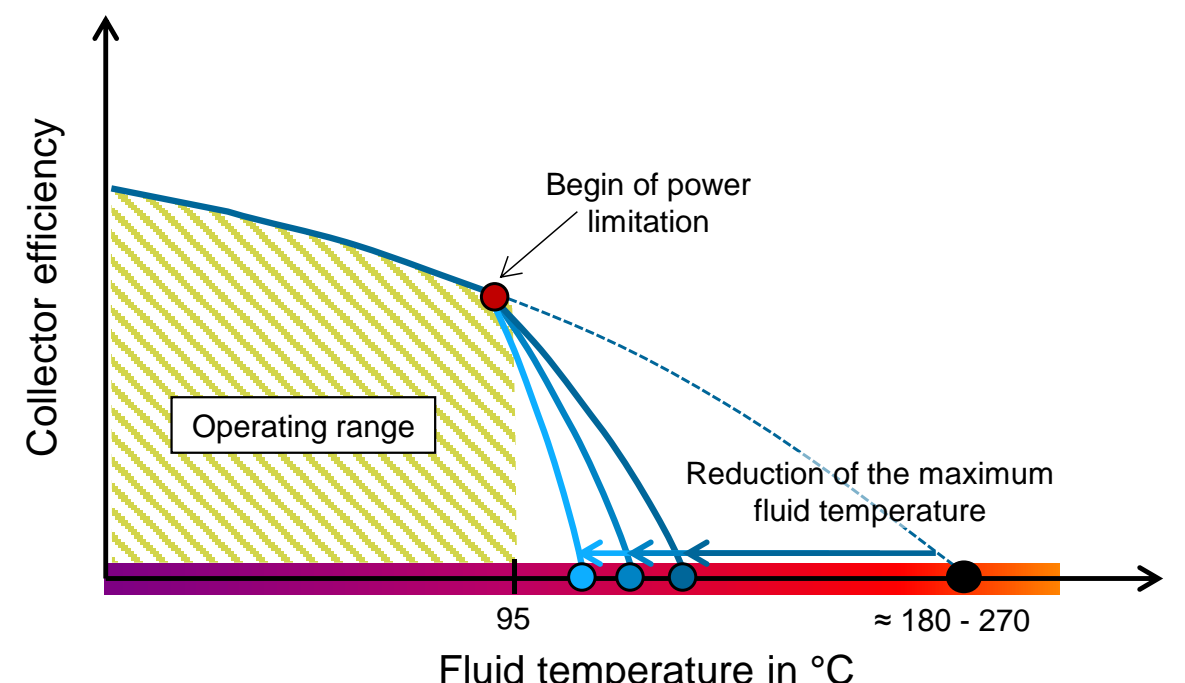

Figure 1: Exemplary efficiency curve of a solar collector with overheating prevention 


\section{Levelized Cost of Heat for Solar Thermal Systems with Overheating Prevention}

\section{INFO Sheet B05}

To determine the overall benefits we adopt the Levelized Cost of Solar Heat ( $\mathrm{LCOH}$ ) method, which was developed in the frame of IEA TASK 54 [5]. The $\mathrm{LCoH}_{\text {sol, fin }}$ represent the total costs of the solar system (costs for components, installations process and maintenance included) with regard to the saving of final energy over an expected system lifetime of 25 years. As exemplary system configuration a typical domestic hot water system (SDHW) with flat plate collectors according to the IEA TASK 54 German reference system ${ }^{1}$ [6] is considered. Thus, the benefits of an optimized system with temperature limitation can be easily assessed in relation to this state-of-the-art system. Such an optimized system features a significantly higher operational safety as well as an extension of service intervals in general. In consequence of avoiding high temperatures and vaporization several components, e.g. the expansion vessel or the solar piping are protected from high thermomechanical stress. This offers the possibility of redesigning such components by adapting their size or using cheaper materials. The following considerations are done for two types of optimizations. In the first case the $\mathrm{LCoH}_{\text {sol,fin }}$ are determined for a "general" optimized system, which can avoid typical stagnation loads independently of a specific technology. In the second case the same calculation is carried out for a "heat pipe" system as concrete approach for a significant temperature limitation.

\section{Optimization of solar circuit components}

The costs of solar circuit components represent a significant part of the investment costs of solar thermal systems. Figure 2 illustrates some simplifications in system design of an optimized system with temperature limitation. The expansion vessel, for example, can be significantly smaller and a ballast vessel is not needed anymore. The resulting cost reduction by resizing these components amounts to $100-140 €$. As a consequence of significantly lower thermal loads the solar station can be optimized as well. A first cost reduction by about $20 €$ is already feasible with commercially available products by replacing temperature sensitive components. Higher savings, by about $100 €$, are expected with a completely new designed polymeric solar station and solar pump. The major part of solar piping and insulation can be made by cheaper polymeric materials. Polyethylene - aluminum multi-layer pipes (PEX-AI-PE) represent a possible alternative to expensive metallic solar pipes. These pipes can be used up to a maximum temperature of $95^{\circ} \mathrm{C}$ (for short time up to $110^{\circ} \mathrm{C}$ ). PEX-Al-PE-pipes are standardized components in the space heating industry and are already supplied as pre-assembled products with insulation. If the maximum temperatures in the close-up range of the collectors are still above $95^{\circ} \mathrm{C}$, a combination of a conventional metallic piping for the first meters and a PEX-Al-PE-pipe for the rest is possible, as shown in Figure 2. The cost reduction depends on the real temperature distribution in the solar circuit and amounts up to $200 €$, if the complete piping can be replaced. In the case of a system with heat pipe flat plat collectors a further cost reduction of about $25 €$ can be achieved by saving solar fluid due to the lower fluid capacity of the heat pipe collector compared to a standard flat plate collector.

\footnotetext{
${ }^{1}$ Specifications of the reference system: $5 \mathrm{~m}^{2}$ collector $\left(\eta_{0}=0.684 ; \mathrm{a}_{1}=3.51 \mathrm{~W} / \mathrm{m}^{2} \mathrm{~K} ; \mathrm{a}_{2}=0.011 \mathrm{~W} / \mathrm{m}^{2} \mathrm{~K}^{2}\right) ; 300 \mathrm{I}$ heat tank.
} 


\section{Levelized Cost of Heat for Solar Thermal Systems with Overheating Prevention}

\section{Simplification of the installation procedure}

Beside the lower costs of optimized components further advantages in the installation procedure can be considered. The focus is on the easier handling of the novel components and on the reduction of working hours, e.g. by using flexible polymeric pipes. Representing such advantages with reliable figures is quite difficult. On the basis of information provided by manufacturers and installers we estimate, that the cost benefit in the installation of the heat pipe system can range between 100 and $250 €$. This time saving can be achieved thanks to an easier pipe laying and flushing, whereby the easier flushing only applies to the case of heat pipe collectors. In the case of the general system (direct flow collectors), we assume that the cost benefit in the installation process ranges between 100 and $190 €$. Thus, the overall investment costs are reduced by $280-630 €$ (general system) and $341-715 €$ (heat pipe system), which represents a relative decrease of up to $19 \%$ compared to the overall investment costs of the reference system.

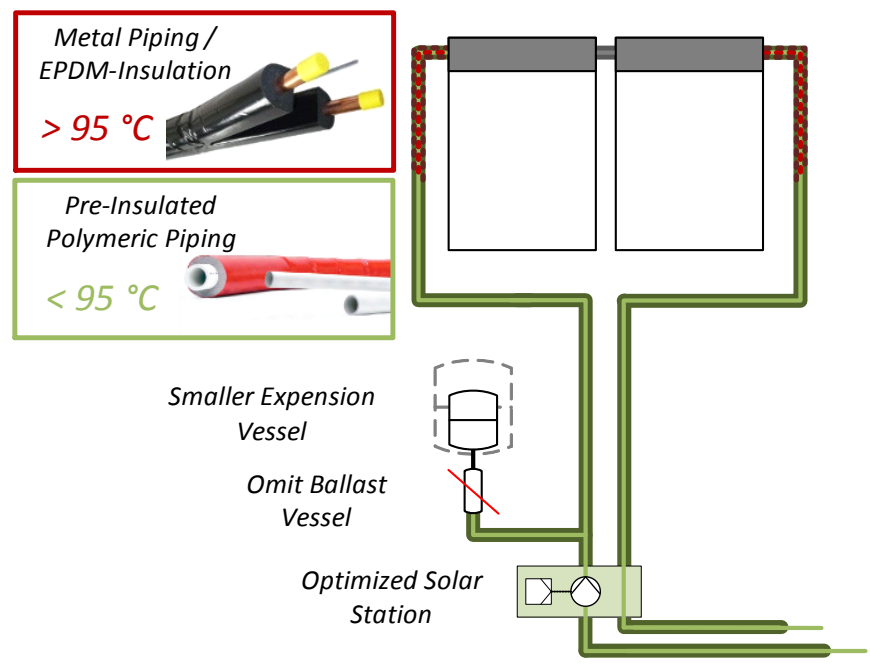

Figure 2: Proposed solar circuit configuration of optimized solar thermal systems with overheating prevention

\begin{tabular}{lrr}
\hline $\begin{array}{l}\text { SDHWS with overheating prevention } \\
\text { (no vapour, temperature limitation) }\end{array}$ & \multicolumn{1}{c}{$\begin{array}{c}\text { General } \\
\text { system }\end{array}$} & $\begin{array}{c}\text { Heat pipe } \\
\text { system }\end{array}$ \\
\hline Less solar fluid & $0 €$ & $25 €$ \\
\hline Smaller expansion vessel / no ballast vessel & $100-140 €$ & $100-140 €$ \\
\hline $\begin{array}{l}\text { Pre-insulated pipes (PEX, PE) } \\
\text { Amount of alternative piping }\end{array}$ & $60-200 €$ & $96-200 €$ \\
\hline Optimized solar station & $50-100 \%$ & $75-100 \%$ \\
\hline $\begin{array}{l}\text { Easier installation } \\
\text { (pipe laying and flushing) }\end{array}$ & $20-100 €$ & $20-100 €$ \\
\hline Total reduction of investment costs & $100-190 €$ & $100-250 €$ \\
\hline Relative benefit of investment costs & $\mathbf{2 8 0 - 6 3 0 €}$ & $\mathbf{3 4 1 - 7 1 5} €$ \\
\hline
\end{tabular}

Figure 3: Cost savings by using cheaper solar circuit components as well as simplifying the installation 


\section{Levelized Cost of Heat for Solar Thermal} Systems with Overheating Prevention

\section{$\mathrm{LCoH}_{\text {sol, fin }}$ of a solar domestic hot water systems with temperature limitation}

For a comprehensive evaluation, the $\mathrm{LCoH}_{\text {sol, fin }}$ of both optimized systems with temperature limitation are determined and compared with the $\mathrm{LCoH}_{\text {sol,fin }}$ of the reference system. Under consideration of the benefits shown in Figure 3 , the average solar investment can decrease from $3850 €$ (reference) to $3395 €$ (general) and $3322 €$ (heat pipe). The significantly lower thermomechanical stress also leads to a lower maintenance effort, especially due to the longer life time of the solar fluid (water-glycol mixture). In [8] a reduction of the yearly maintenance costs by more than $50 \%$ is estimated, as a consequence of avoiding typical stagnation loads. The annual yield is defined as saved final energy and essentially depends on the collector thermal performance parameters. We assume that both optimized systems reach the same thermal performance as the reference system in order to focus only on the benefits related to the temperature limitation and not to other effects ${ }^{2}$. Figure 4 shows the $\mathrm{LCoH}_{\text {sol, fin }}$ of the general and the heat pipe system compared to the benchmark, which represents the costs of the reference system. The average $\mathrm{LCoH}_{\text {sol,fin }}$ are reduced from $11.3 € \mathrm{ct} / \mathrm{kWh}$ to $8.7 € \mathrm{ct} / \mathrm{kWh}$ (general) and $8.3 € \mathrm{ct} / \mathrm{kWh}$ (heat pipe). That means an overall cost reduction of $31 \%$ (best case scenario) by using heat pipe collectors with temperature limitation.

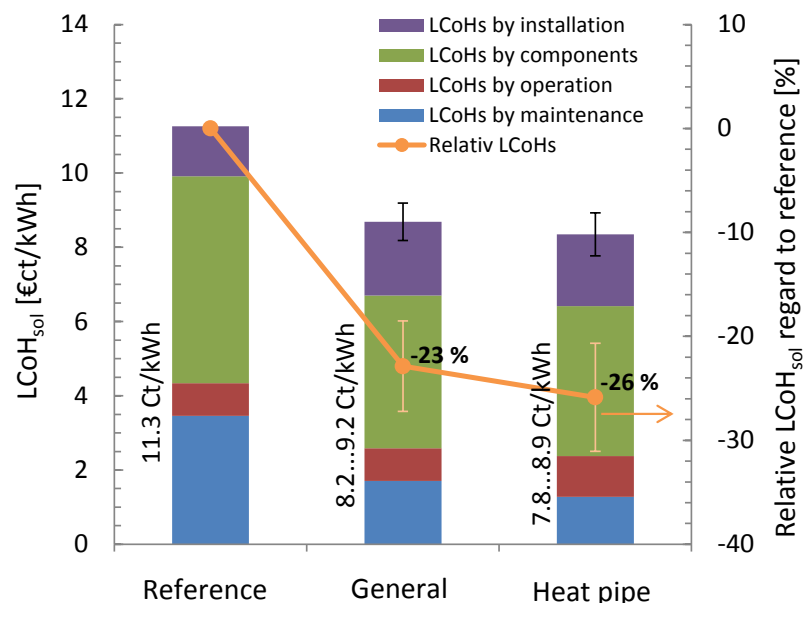

\begin{tabular}{lccc}
\hline & $\begin{array}{c}\text { Reference } \\
\text { system }\end{array}$ & $\begin{array}{c}\text { General } \\
\text { system }\end{array}$ & $\begin{array}{c}\text { Heat pipe } \\
\text { system }\end{array}$ \\
\hline Solar investment [€] & 3850 & $3220-3570$ & $3135-3509$ \\
Annual maintenance [€/a] & 77 & $39 \pm 5$ & $34 \pm 5$ \\
Annual yield [kWh/a] & 2226 & 2226 & 2226 \\
LCoH $_{\text {sol,fin }}[€ \mathbf{c t} / \mathbf{k W h}]$ & $\mathbf{1 1 . 3}$ & $\mathbf{8 . 7} \pm \mathbf{0 . 5}$ & $\mathbf{8 . 3} \pm \mathbf{0 . 6}$ \\
Cost reduction [\%] & - & $\mathbf{2 3} \pm \mathbf{4}$ & $\mathbf{2 6 \pm \mathbf { 5 }}$ \\
\hline
\end{tabular}

Figure 4: Levelized Cost of Solar Heat $\left(\mathrm{LCoH}_{\text {sol, fin }}\right)$ and relative cost reduction of the general system and the heat pipe system compared to the reference system for a system lifetime of 25 years

\footnotetext{
${ }^{2}$ Comparable system performances have been already attested for heat pipe and thermochromic collectors by means
} of experimental investigations on prototypes. 


\section{Levelized Cost of Heat for Solar Thermal

\section{References}

[1] Schiebler, B.; Weiland F.; Giovannetti, F.; Jack, S.: Entwicklung und Bewertung von Flachkollektoren mit Wärmerohren zur Begrenzung der Stagnationstemperatur in Solarkreisen. Symposium Solarthermie Technik für die Wärmewende, Bad Staffelstein, 13.-15. Juni 2018.

[2] Mientkewitz, G.; Zabel, J.: Möglichkeiten eines Heatpipe-Kollektors ohne Stagnationsprobleme. 20. OTTI Symposium Thermische Solarenergie, Bad Staffelstein, 2010.

[3] Müller, S.; Reineke-Koch, R.; Giovannetti, F.; Hafner, B.: Flat Plate Collectors with Thermochromic Absorber Coatings under Dynamic System Tests, ISES Solar World Congress 2017, Conference Proceedings p. 2117-2125, 2018.

[4] Thür, A.; Neyer, J.; Streicher, W.: Entwicklung eines physikalischen Kollektormodells mit eigensicherer Temperaturbegrenzung, Konferenzbeitrag 23. OTTI Symposium Thermische Solarenergie, Bad Staffelstein, 2013.

[5] Louvet, Y.; Fischer, S.; Furbo, S.; Giovannetti, F.; Köhl, M.; Mauthner, F.; Mugnier, D.; Phillippen, D.; Veynandt, F.: Guideline for levelized cost of heat $(\mathrm{LCOH})$ calculations for solar thermal applications. IEA TASK 54 Info Sheet A01, 2018.

[6] Bachmann, S.; Fischer, S; Furbo, S.; Hafner, B.: Definition of the reference solar domestic hot water (SDHW) system, Germany. Info Sheet A09, SHC IEA TASK 54, 2018.

[7] Verein Deutscher Ingenieure e.V. (VDI): VDI 2067 Blatt 1:2012, Wirtschaftlichkeit gebäude-technischer Anlagen - Grundlagen und Kostenberechnung, Beuth Verlag, Berlin 2012.

[8] Schiebler, B.; Giovannetti, F.; Fischer, S: Reduction of maintenance costs by preventing overheating. Info Sheet B03, SHC IEA TASK 54, 2018. 